\title{
PENGARUH LABELISASI HALAL TERHADAP KEPUTUSAN PEMBELIAN PRODUK MI INSTAN PADA MAHASISWA JURUSAN EKONOMI SYARIAH INSTITUT AGAMA ISLAM NEGERI PADANGSIDIMPUAN
}

\author{
Darwis Harahap', Nando Farizal'2, Masbulan Nasution ${ }^{3}$ \\ Institut Agama Islam Negeri Padangsidimpuan \\ Jalan T. Rizal Nurdin Km. 4,5 Sihitang, Padangsidimpuan \\ E-mail:darwiso5@yahoo.com
}

\begin{abstract}
Abstrak,
Latar belakang masalah dari penelitian ini adalah untuk mengetahui kepedulian Mahasiswa Jurusan Ekonomi Syariah dalam memperhatikan label halal pada kemasan produk pangan pada saat mengambil keputusan pembelian. Tujuan penelitian ini adalah untuk mengetahui apakah ada pengaruh labelisasi halal terhadap keputusan pembelian produk mi instan pada Mahasiswa Jurusan Ekonomi Syariah Institut Agama Islam Negeri Padangsidimpuan. Penelitian ini merupakan penelitian kuantitatif. Sumber data yang digunakan adalah data primer. Teknik pengumpulan data yang digunakan adalah angket, dengan jumlah sampel 91 responden. Alat analisis yang digunakan adalah uji validitas dan reliabilitas, uji normalitas, uji linearitas, analisis regresi sederhana, uji t, dan uji koefisien determinasi ( $R$ square). Dengan menggunakan program SPSS Versi 21. Hasil penelitian menunjukkan bahwa labelisasi halal memberikan pengaruh positif terhadap keputusan pembelian.
\end{abstract}

Kata Kunci : Label Halal, Mahasiswa, Keputusan Pembelian

\begin{abstract}
,
The background of the problem of this research is to find out the concern of the Students of the Islamic Economics Department in paying attention to the halal labels on food product packaging when making purchasing decisions. The purpose of this study was to find out whether there was an effect of halal labeling on the decision to purchase instant noodles products in the Students of the Islamic Economics Department of the Padangsidimpuan State Islamic Institute. This research is quantitative research. The data source used is primary data. The data collection technique used was a questionnaire, with a sample of 91 respondents. The analytical tool used is validity and reliability test, normality test, linearity test, simple regression analysis, $t$ test, and test the coefficient of determination ( $R$ square). By using the SPSS Version 21 program. The results showed that halal labeling had a positive influence on purchasing decisions.
\end{abstract}

Keywords: Halal Label, Student, Purchasing Decision 


\section{PENDAHULUAN}

Dalam ruang lingkup Mahasiswa Jurusan Ekonomi Syariah Institut Agama Islam Negeri Padangsidimpuan dapat dijadikan contoh kecil komunitas Islam mewakili komunitas Islam lainnya yang mengonsumsi produk halal. Mahasiswa memiliki akses dan informasi yang lebih luas sehingga lebih kritis terhadap suatu hal. Mereka dapat membedakan suatu produk dengan produk lainnya berdasarkan informasi yang mereka peroleh, namun beberapa Mahasiswa juga terkadang tidak memperhatikan kemasan produk yang mereka konsumsi, apakah memiliki label halal atau tidak. Produk yang berlabel halal yang akan diteliti dalam penelitian ini adalah produk mi instan yang merupakan salah satu makanan favorit Mahasiswa.

Hasil wawancara peneliti dengan beberapa Mahasiswa Jurusan Ekonomi Syariah Institut Agama Islam Negeri Padangsidimpuan yang merupakan penggemar produk makanan dalam kemasan termasuk mi instan menyatakan bahwa, setiap kali membeli suatu produk makananmasih jarang sekali memperhatikan kemasan produk tersebut berlabel halal atau tidak, adanya rasa sukadan rasa yakin terhadap produk makanan tersebut membuat konsumen melakukan pembelian, bukan karena ada atau tidaknya label halal. Harga yang terjangkau dan lokasi produk makanan yang diinginkan juga menjadi pertimbangan yang penting bagi konsumen, dibanding memperhatikan kemasan produk makanan tersebut berlabel halal atau tidak (Fatimah dan Rayani, 2017).

Dengan demikian, beberapa konsumen ternyata masih ada yang tidak memperhatikan kemasan produk makanan apakah berlabel halal atau tidak ketika akan mengonsumsinya. Dengan adanya penelitian ini peneliti berharap para konsumen Muslim seharusnya mampu lebih peduli dan memperhatikan lagi setiap apa yang dikonsumsinya. Labelisasi halal yang secara prinsip adalah label yangmenginformasikan kepada pengguna produk yang berlabel tersebut, bahwa produknya benar-benar halal dan nutrisi-nutrisi yang dikandungnya tidak mengandung unsur-unsuryang diharamkan secara syariah sehingga produk tersebut boleh dikonsumsi. Dengandemikian konsumen Muslim dapat mengonsumsi produk dengan rasa aman dan tenang. Sedangkan, produk-produk yang tidak mencantumkan label halal pada kemasannyaakan membuat konsumen Muslim memiliki kekhawatiran dalam mengonsumsinya, dan produk tersebut dianggap belum mendapat persetujuan lembaga berwenang (LPPOM MUI) untukdiklasifikasikan kedalam daftar produk halal atau dianggap masih diragukankehalalannya.

Lembaga Pengkajian Pangan, Obat-obatan dan KosmetikaMajelis Ulama Indonesia (LPPOM MUI), merupakan sebuahlembaga yang dibentuk oleh MUI dengan tugas 
menjalankanfungsi MUI untuk melindungi konsumen muslim dalam mengonsumsi makanan, minuman, obat-obatan maupunkosmetika (Hosen, 2008). LPPOM MUI memiliki kewenangan untuk mengeluarkan sertifikasi halal, dan atas dasar itu Badan Pengawas Obat dan Makanan (Badan POM) mengeluarkan label halal untuk produk yang telah disertifikasi oleh Lemabaga Pengkajian Pangan, Obata-obatan dan Kosmetika Majelis Ulama Indonesa (LPPOM MUI). Gambar label halal yang resmi dari MUI adalah sebagai berikut:

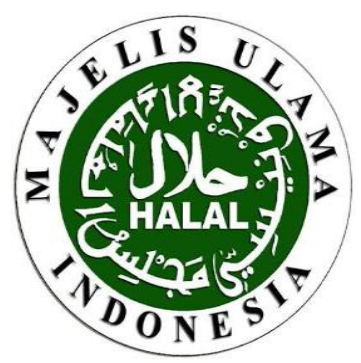

\section{Gambar 1. Label Halal Resmi MUI}

Sumber: www.halalmui.org

Label halal di Indonesia sendiri sangatlah mudah untuk ditemukan, umumnya pada produk makanan dalam kemasan. Produk yang tidak jelas bahan bakunya dan pengolahannya pun dapat ditempeli tulisan halal oleh produsen untuk meyakinkan konsumen bahwa produk tersebut halal. Contoh label halal palsu yang sering digunakan oleh produsen adalah sebagai berikut:

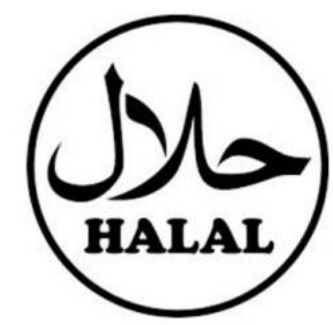

\section{Gambar 2. Label Halal Tanpa Ada Lembaga Yang Menjaminnya}

Sumber: www.ahlulbaitindonesia.or.id

Pemahaman yang semakin baik tentang agama semakin membuat konsumenMuslim menjadi semakin selektif dalam pemilihan produk yang dikonsumsi. Khusus diIndonesia, konsumen Muslim dilindungi oleh lembaga yang secara khusus bertugasuntuk mengaudit produk-produk yang dikonsumsi oleh konsumen Muslim di Indonesia yaitu LPPOM MUI.

Pada dasarnya konsumen memiliki persepsi yang berbeda untuk mengambil keputusan dalam membeli produk makanan, sebagian mungkin tidak peduli dengan kehalalan suatu produk 
PENGARUH LABELISASI HALAL TERHADAP KEPUTUSAN PEMBELIAN PRODUK MI INSTAN

PADA MAHASISWA JURUSAN EKONOMI SYARIAH

INSTITUT AGAMA ISLAM NEGERI PADANGSIDIMPUAN

Darwis Harahap, Nando Farizal, Masbulan Nasution dan sebagian lainnya masih sangat berpegang teguh dengan prinsip bahwa untuk mengonsumsi suatu produk haruslah halal.Seperti hasil wawancara peneliti dengan salah satu Mahasiswi Jurusan Ekonomi Syariah Institut Agama Islam Negeri Padangsidimpuan, bahwa setiap kali ingin membeli suatu produk makanankehalalannya pasti selalu dijadikan pertimbangan dengan memastikan apakah pada kemasan produk tersebut terdapat label halal atau tidak, bukan hanya label halalnyatetapi jaminan dari BPOM dan tanggal kadaluarsanya juga pasti diperhatikan (Devi, 2017). Dengan demikian, kebutuhan akan produk halal yang dirasakan oleh konsumen seharusnya mampu diatasi oleh para produsen dengan menciptakan atau menyediakan produkproduk makanan yang halal.

Peneliti memilih produk mi instan yang akan menjadi pilihan Mahasiswa dalam mengonsumsi produk makanan yang berlabel halal karena berbagai jenis merek mi instan yang berlabel halal resmi dari MUI telah banyak beredar di masyarakat. Mi instan merupakan produk pilihan Mahasiswa yang mudah didapatkan dan harganya terjangkau oleh Mahasiswa serta menjadi salah satu makanan yang dijadikan makanan favorit dikalangan Mahasiswa. Kehidupan Mahasiswa yang sebagian besar adalah anak kos, membuat mi instan sebagai cadangan makanan ketika di akhir bulan keuangan mulai menipis. Tetapi tidak jarang juga sebagian Mahasiswa memang suka mengonsumsi mi instan kapan saja dan di mana saja, bukan hanya karena keuangan menipis tetapi juga karena mi instan memiliki rasa yang enak, mudah dan cepat disajikan, dan dapat mengganjal perut lapar ketika sedang berada di luar rumah atau kos, seperti saat berada di kampus.

\section{TINJAUAN TEORITIK}

\section{Perilaku Konsumen}

Istilah konsumen sering diartikan sebagai dua jenis konsumen, yaitu; konsumen individu dan konsumen organisasi. Konsumen individu membeli barang dan jasa untuk digunakan sendiri. Konsumen organisasi meliputi organisasi bisnis, yayasan, lembaga sosial, kantor pemerintah, dan lembaga lainnya (sekolah, perguruan tinggi, dan rumah sakit). Semua jenis organisasi ini harus membeli produk peralatan dan jasa-jasa lainnya untuk menjalankan seluruh kegiatan organisasinya. Konsumen individu dan konsumen organisasi adalah sama pentingnya. Mereka memberikan sumbangan yang sangat besar bagi perkembangan dan pertumbuhan ekonomi. Konsumen akhir memiliki keragaman yang menarik untuk dipelajari, karena ia meliputi seluruh individu dari berbagai usia, latar belakang budaya, pendidikan dan keadaan sosial ekonomi lainnya (Sumarwan, 2015). 
Perilaku konsumen pada hakikatnya untuk memahami 'Why do consumers do what they do'. Perilaku konsumen adalah semua kegiatan, tindakan, serta proses psikologis yang mendorong tindakan tersebut pada saat sebelum membeli, ketika membeli, menggunakan, menghabiskan produk dan jasa setelah melakukan hal-hal di atas atau kegiatan mengevaluasi (Sumarwan, 2013). Perilaku pembelian konsumen dipengaruhi oleh faktor-faktor budaya, sosial, pribadi, dan psikologis. Yang mempunyai pengaruh paling luas dan paling dalam adalah faktorfaktor budaya (Kotler \& Keller, 2007).

a. Faktor Budaya

Budaya, sub-budaya, dan kelas sosial sangat penting bagi perilaku pembelian. Budaya merupakan penentu keinginan dan perilaku paling mendasar. Anak-anak yang sedang bertumbuh mendapatkan seperangkat nilai, persepsi, preferensi, dan perilaku dari keluarga dan lembaga-lembaga penting lain (Kotler \& Keller, 2007). Budaya merupakan faktor penentu keinginan dan perilaku seseorang yang paling mendasar. Perilaku manusia akan sangat dipengaruhi oleh kebudayaan dimana ia bertempat tinggal dan pengaruh tersebut akan terus ada dan terus berubah mengikuti perkembangan zaman.

b. Faktor Sosial

Faktor-faktor sosial yang berpengaruh terhadap perilaku konsumen diantaranya: kelompok acuan, keluarga, peran dan status dalam masyarakat.

1) Kelompok Acuan

Kelompok acuan adalah sekelompok orang yangsecara nyata mempengaruhi pelaku seseorang. Kelompok acuan digunakan oleh seseorang sebagai dasar untuk perbandingan atau sebuah referensi dalam membentuk respons efektif, kognitif, dan perilaku. Kelompok acuan akan memberikan standar dan nilai yang akan mempengaruhi perilaku seseorang (Sumarwan, 2015).

Kelompok acuan seseorang terdiri atas semua kelompok di sekitar individu yang mempunyai pengaruh baik langsung maupun tidak langsung terhadap perilaku individu tersebut. Kelompok acuan mempengaruhi pendirian dan konsep pribadi seseorang karena individu biasanya berhasrat untuk berperilaku sama dengan kelompok acuan tersebut.

2) Keluarga 

Keluarga adalah lingkungan mikro, yaitu lingkungan yang paling dekat dengan konsumen. Keluarga adalah lingkungan dimana sebagian besar konsumen tinggal dan berinteraksi dengan anggota-anggota keluarga lainnya. Keluarga menjadi daya tarik bagi para pemasar, karena keluarga memiliki pengaruh yang besar kepada konsumen. Anggota keluarga akan saling mempengaruhi dalam pengambilan keputusan pembelian produk dan jasa (Sumarwan, 2015).

3) Peran dan Status dalam Masyarakat

Peranan adalah kegiatan yang diharapkan untuk dilakukan mengacu pada orang-orang di sekellilingnya. Sedangkan status adalah pengakuan umum masyarakat sesuai dengan peran yangdijalankan. Setiap individu dan status yang disandangnya akan mempengaruhi perilakunya.

c. Faktor Pribadi

Keputusan individu dalam melakukan pembelian bisa dipengaruhi oleh faktor-faktor pribadi berbeda-beda antara satu individu dengan individu lainnya. Faktor-faktor tersebut diantaranya:

1) Usia dan Tahap Siklus Hidup

Individu dalam membeli barang atau jasa biasanya disesuaikan dengan perubahan usia mereka. Pola konsumsi yang terbentuk juga berbeda antara individu-individu yang usianya berbeda.

2) Pekerjaan

Pekerjaan individu tentunya ikut mempengaruhi perilaku pembelian individu. Penghasilan yang mereka peroleh dari pekerjaannya itulah yang menjadi determinan penting dalam perilaku pembelian mereka.

3) Gaya Hidup

Gaya hidup seseorang adalah pola hidup di dunia yang diekspresikan oleh kegiatan, minat, dan pendapat seseorang. Gaya hidup meggambarkan “seseorang secara keseluruhan" yang berinteraksi dengan lingkungan. Gaya hidup juga mencerminkan sesuatu dibalik kelas sosial seseorang (Setiadi, 2010).

4) Kepribadian

Yang dimaksud dengan kepribadian adalah karakteristik psikologis yang berbeda dari setiap orang yang memandang responnya terhadap lingkungan yang relatif konsisten, kepribadian merupakan suatu variabel yang sangat 
berguna dalam menganalisis perilaku konsumen, bila jenis-jenis kepribadian dapat diklasifikasikan dan memiliki korelasi yang kuat antara jenis-jenis kepribadian tersebut dan berbagai pilihan produk atau merek (Setiadi, 2010).

d. Faktor Psikologi

1) Motivasi

Motivasi dapat digambarkan sebagai tenaga pendorong dalam diri individu yang memaksa mereka untuk bertindak. Tenaga pendorong tersebut dihasilkan oleh keadaaan tertekan yang timbul sebagai akibat kebutuhan yang tidak terpenuhi. Individu secara sadar maupun tanpa sadar berjuang untuk mengurangi ketegangan ini melalui perilaku yang mereka harapkan akan memenuhi kebutuhan mereka dan dengan demikian akan membebaskan mereka dari tekanan yang mereka rasakan (Schiffman dan Kanuk, 2004).

2) Persepsi

Persepsi didefinisikan sebagai proses di mana seseorang memilih, mengorganisasikan, mengartikan masukan informasi untuk menciptakan suatu gambaran yang berarti dari dunia ini. Orang yang dapat memiliki persepsi yang berbeda dari objek yang sama karena adanya tiga proses persepsi, yaitu perhatian yang selektif, gangguan yang selektif, dan mengingat kembali yang selektif. Faktor-faktor persepsi ini mengartikan bahwa para pemasar harus bekerja keras agar pesan yang disampaikan diterima (Schiffman dan Kanuk, 2004).

3) Sikap

Selain persepsi akan muncul pula sikap seseorang dalam menilai suatu obyek yang akan diminati dan untuk dimiliki. Sikap sebagai evaluasi yang menyeluruh dan memungkinkan seseorang untuk merespon dengan cara yang menguntungkan atau tidak terhadap obyek yang dinilai.

Perliaku konsumen Muslim yang menjadikan makanan halal sebagai pertimbangannya dalam mengonsumsi suatu makanan, yaitu sesuai dengan penelitian ini merupakan perilaku konsumen yang dipengaruhi oleh faktor pribadi. Salah satu faktor yang termasuk faktor pribadi adalah gaya hidup konsumen tersebut. Konsumen Muslim akan cenderung memiliki gaya hidup atau pola konsumsi yang memenuhi aturan syariat, yaitu mengonsumsi makanan yang halal, walaupun tidak semua konsumen Muslim patuh dengan ajaran syariat tersebut, karena setiap konsumen memiliki pola konsumsi yang berbeda-beda. Tetapi konsumen Muslim yang taat pada 
PENGARUH LABELISASI HALAL TERHADAP KEPUTUSAN PEMBELIAN PRODUK MI INSTAN

PADA MAHASISWA JURUSAN EKONOMI SYARIAH

INSTITUT AGAMA ISLAM NEGERI PADANGSIDIMPUAN

Darwis Harahap, Nando Farizal, Masbulan Nasution ajaran Islam akan memiliki gaya hidup atau pola konsumsi yang sesuai dengan ajaran islam termasuk mengonsumsi makanan yang halal dan baik.

\section{Keputusan Pembelian Konsumen}

Menurut pemahaman yang paling umum, sebuah keputusan adalah seleksi terhadap dua pilihan alternatif atau lebih. Dengan perkataan lain, pilihan alternatif harus tersedia bagi seseorang ketika mengambil keputusan. Jika seseorang mempunyai pilihan antara melakukan pembelian dan tidak melakukan pembelian, pemilihan antara merek X dan Merek Y, atau pilihan untuk menggunakan waktu mengerjakan A atau B, orang tersebut berada dalam posisi untuk mengambil keputusan. Sebaliknya, jika konsumen tersebut tidak mempunyai alternatif untuk memilih dan benar-benar terpaksa melakukan pembelian tertentu atau mengambil tindakan tertentu (misalnya, menggunakan obat resep dokter), maka keadaaan satu-satunya "tanpa pilihan lain” ini bukanlah suatu keputusan. Keputusan atas keadaan tanpa pilihan biasanya disebut "pilihan Hobson" (Schiffman dan Kanuk, 2004).

Inti dari pengambilan keputusan konsumen (consumer decision making) adalah proses pengintegrasian yang mengombinasikan pengetahuan untuk mengevaluasi dua atau lebih perilaku alternatif,dan memilih salah satu diantaranya. Hasil dari proses pengintegrasian ini ialah suatu pilihan (choice), yang disajikan secara kognitif sebagai keinginanberperilaku (Setiadi, 2010). Konsumen seringkali ada lebih dari dua pihak yang terlibat dalam prosespertukaran atau pembelian.

Menurut Kotler \& Keller (2007), proses pengambilan keputusan pembelian dibagi dalam 5 (lima) tahapan, yaitu:

a. Pengenalan Masalah; Proses pembelian dimulai ketika pembeli mengenali masalah atau kebutuhan. Kebutuhan tersebut dapat dicetuskan oleh rangsangan internal atau eksternal. Para pemasar perlu mengidentifikasi keadaan yang memicu kebutuhan tertentu, dengan mengumpulkan informasi dari sejumlah konsumen. Mereka kemudian dapat menyusun strategi pemasaran yang mampu memicu minat konsumen.

b. Pencarian Informasi; Konsumen yang terangsang kebutuhannya akan terdorong untuk mencari informasi yang lebih banyak. Sumber informasi konsumen digolongkan ke dalam empat kelompok berikut ini:

1) Sumber pribadi: Keluarga, teman, tetangga, kenalan.

2) Sumber Komersial: Iklan, Wiraniaga, penyalur, kemasan, pajangan di toko.

3) Sumber publik: Media massa, organisasi penentu peringkat konsumen. 
4) Sumber pengalaman: Penanganan, pengkajian, dan pemakaian produk.

c. Evaluasi Alternatif; Pada tahap ini, konsumen mengolah informasi merek yang bersaing dan membuat penilaian akhir. Beberapa konsep dasar akan membantu kita memahami proses evaluasi konsumen. Pertama, konsumen berusaha memenuhi kebutuhan. Kedua, konsumen mencari manfaat tertentu dari solusi produk. Ketiga, konsumen memandang masing-masing produk sebagai sekumpulan atribut dengan kemampuan yang berbeda-beda dalam memberikan manfaat yang digunakan untuk memuaskan kebutuhan itu.

d. Keputusan Pembelian; Dalam tahap ini para konsumen membentuk preferensi atas merek-merek yang ada di dalam kumpulan pilihan. Kemudian konsumen juga dapat membentuk niat untuk membeli merek yang paling disukai.

e. Perilaku Pasca Pembelian; Setelah pembelian, konsumen mungkin mengalami ketidaksesuaian karena memerhatikan fitur-fitur tertentu yang menggangu atau mendengar hal-hal yang menyenangkan tentang merk lain, dan akan selalu siaga terhadap informasi yang mendukung keputusannya.

\section{Konsumsi dalam Ekonomi Islam}

Konsumsi dalam ekonomi Islam dapat didefinisikan dengan memakan makanan yang baik, halal dan bermanfat bagi manusia, dan pemanfaatan segala anugerah Allah SWT. di muka bumi, atau sebagai sebuah kebajikan, karena kenikmatan yang diciptakan Allah untuk manusia adalah wujud ketaatan kepada-Nya (Tarigan, 2006). Sebagaimana firman Allah SWT. dalam surah Al-Baqarah sebagai berikut:

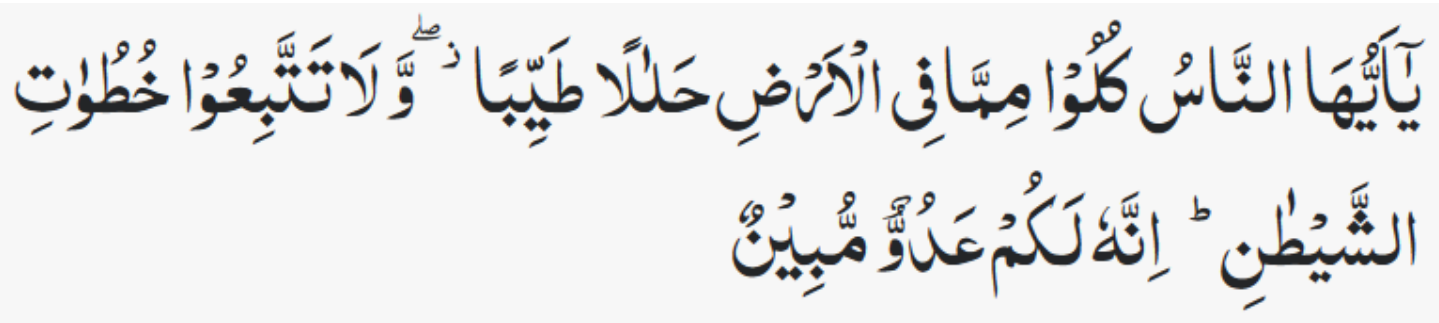

Artinya:"Wahai manusia! Makanlah dari (makanan) yang halal dan baik yang terdapat di bumi, dan janganlah kamu mengikuti langkah-langkah setan. Sungguh, setan itu adalah musuh yang nyata bagimu”. (Q.S. Al-Baqarah:168) (Kementerian Agama Republik Indonesia, 2006). 
PENGARUH LABELISASI HALAL TERHADAP KEPUTUSAN PEMBELIAN PRODUK MI INSTAN

PADA MAHASISWA JURUSAN EKONOMI SYARIAH

INSTITUT AGAMA ISLAM NEGERI PADANGSIDIMPUAN

Darwis Harahap, Nando Farizal, Masbulan Nasution

Makanan bahasa Arabnya adalah ța'am. Adapun pengertian ța'am secara istilah berarti segala sesuatu yang bisa dimakan secara mutlak. Sedangkan minuman dalam bahasa Arabnya adalah syarab. Sementara syarab adalah sebutan untuk segala yang diminum dari jenis apapun, baik air maupun selainnya, dan dalam keadaan bagaimanapun. Setiap sesuatu yang tidak dikunyah untuk menelannya maka disebut sebagai minuman (Fida, 2014).

Hukum asal makanan adalah halal, hingga ada dalil yang mengharamkannya (Kementerian Agama Republik Indonesia, 2006). Allah SWT. berfirman:

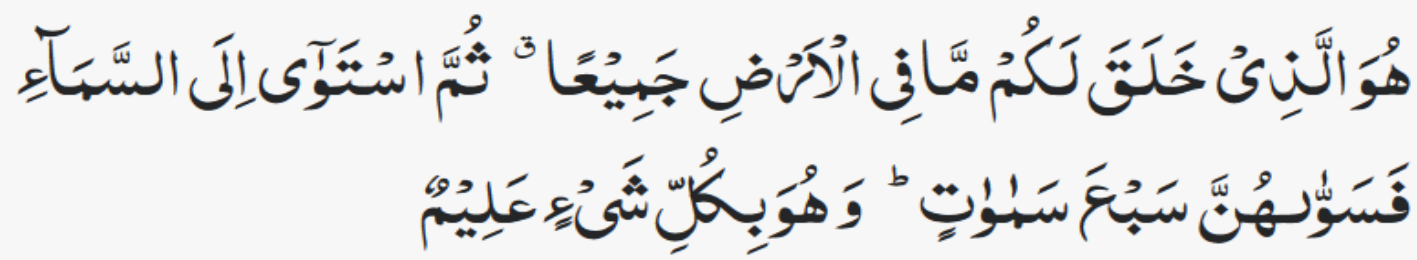

Artinya: "Dialah Allah yang menjadikan segala yang ada di bumi untukmu...”(Q.S. AlBaqarah: 29) (Kementerian Agama Republik Indonesia, 2006).

Haram adalah sesuatu yang Allah SWT. melarang untuk dilakukandengan larangan yang tegas. Setiap orang yang menentangnya akanberhadapan dengan siksaan Allah di akhirat. Bahkan terkadang jugaterancam sanksi syariah di dunia ini (Hosen, 20o8). Bahan makanan yang Allah haramkan telah Allah jelaskan dalam Al Quran surah Al-Baqarah, yaitu sebagai berikut:

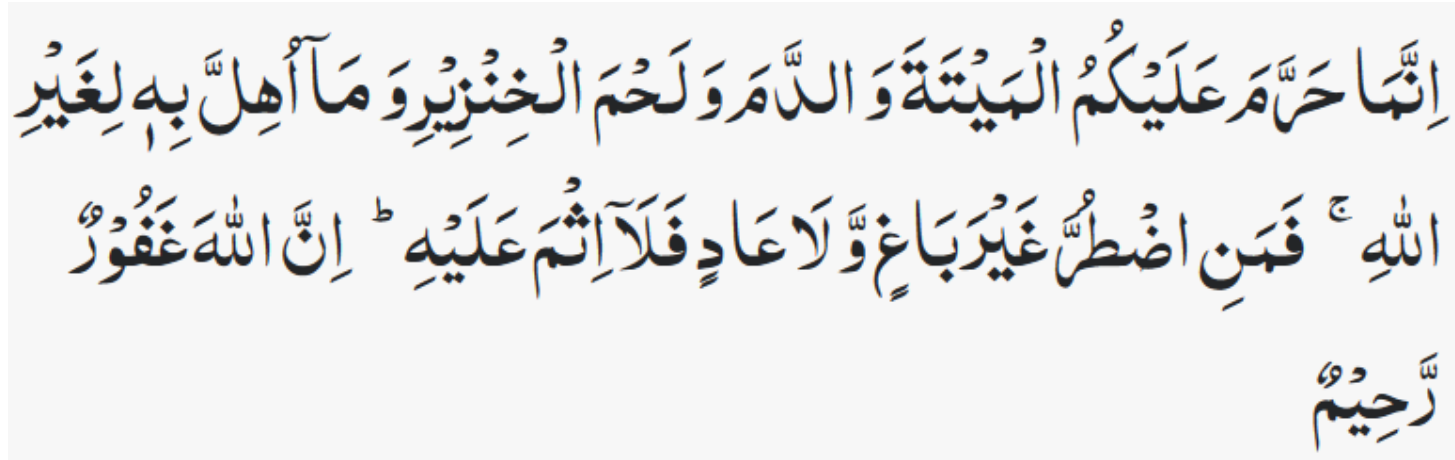

Artinya: "Sesungguhnya Dia hanya mengharamkan atasmu bangkai,darah, daging babi, dan (daging) hewan yang disembelih dengan (menyebutnama) selain Allah. Tetapi barang siapa terpaksa (memakannya), bukan karena menginginkannya dan tidak (pula) melampaui batas, maka tidak ada dosa baginya. Sungguh, Allah Maha Pengampun, Maha Penyayang”.(Q.S. Al-Baqarah:173) (Kementerian Agama Republik Indonesia, 2006). 
Konsumsi pada hakikatnya adalah mengeluarkan sesuatu dalam rangka memenuhi kebutuhan. Konsumsi meliputi keperluan, kesenangan dan kemewahan. Kesenangan atau keindahan diperbolehkan asal tidak berlebihan, yaitu tidak melampaui batas yang dibutuhkan oleh tubuh dan tidak pula melampaui batas-batas makanan yang dihalalkan (Diana, 2012). Sebagaiamana firman Allah SWT. dalam Al Quran surah AlA'raf sebagai berikut:

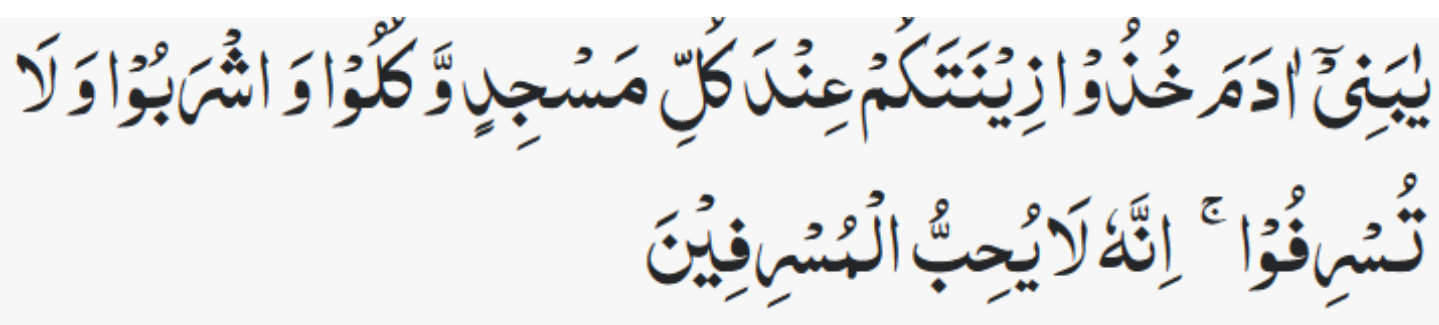

Artinya: "Wahai anak cucu Adam!Pakailah pakaianmu yang baguspadasetiap (memasuki) masjid, makan dan minumlah, tetapi jangan berlebihan. Sungguh, Allah tidak Menyukai orang yang berlebih-lebihan”.(Q.S. Al-A'raf:31) (Kementerian Agama Republik Indonesia, 2006).

Bila dalam mengonsumsi sesuatu kemungkinan mengandung mudarat atau maslahahmaka menghindari kemuḍaratanharus lebih diutamakan, karena akibat dari kemuḍaratanyang ditimbulkan mempunyai ekses yang lebih besar daripada mengambil sedikit manfaatnya. Jadi, perilaku konsumsi seorang Muslim harus senantiasa mengacu pada tujuan syariat, yaitu memelihara maslahah dan menghindari mudarat (Rozalinda, 2014).

Maslahah dalam ekonomi Islam diterapkan sesuai dengan prinsip rasionalitas Muslim, bahwa setiap pelaku ekonomi selalu ingin meningkatkan maslahah yang diperolehnya. Seorang konsumen Muslim mempunyai keyakinan bahwasanya kehidupan tidak hanya di dunia tetapi akan ada di akhirat kelak. Imam Asy-Syathibi mengatakan bahwa kemaslahatan manusia dapat terealisasi apabila lima unsur pokok dapat diwujudkan dan dipelihara, yaitu agama ( $a d$-din), jiwa, (an-nafs), akal (al-'aql), keturunan (an-nasl) dan harta (al-mal). Semua pemenuhan kebutuhan barang dan jasa adalah untuk mendukung terpeliharanya kelima unsur pokok tersebut. Tujuannya bukan hanya kepuasan di dunia, tetapi juga kesejahteraan di akhirat (Rozalinda, 2014).

Dalam konsumsi, prinsip dasar yang harus dijadikan sebagai acuan adalah sebagai berikut (Tarigan,2006) 
PENGARUH LABELISASI HALAL TERHADAP KEPUTUSAN PEMBELIAN PRODUK MI INSTAN

PADA MAHASISWA JURUSAN EKONOMI SYARIAH

INSTITUT AGAMA ISLAM NEGERI PADANGSIDIMPUAN

Darwis Harahap, Nando Farizal, Masbulan Nasution

a. Prinsip kebenaran, yaitu mengajarkan kepada manusia untuk mempergunakan barang-barang yang dibenarkan oleh syara', baik dari segi zat, cara memproduksi, maupun tujuan dari mengonsumsi tersebut.

b. Prinsip kebersihan,yang berarti bahwa barang yang dikonsumsi harus bersih, baik, berguna dan sesuai untuk dimakan.

c. Prinsip kesederhanaan, yaitu menganjurkan agar konsumsi sampai tingkat minimum (standar) sehingga bisa mengekang hawa nafsu dan keinginan yang berlebihan.

d. Prinsip kemaslahatan, yang berarti bahwa konsumen boleh mengonsumsi barang selagi barang tersebut mampu memberikan kebaikan serta kesempurnaan dalam usaha mengabdikan diri kepada Allah.

e. Prinsip akhlak, yaitu menunjukkan bahwa konsumsi harus dapat memenuhi etika, adat kesopanan dan perilaku terpuji seperti syukur, zikir, dan fikir serta sabar dan mengesampingkan sifat-sifat tercela seperti kikir dan rakus.

\section{Labelisasi Halal}

Label adalah bagian dari sebuah barang yang berupa keterangan (kata-kata) tentang barang tersebut atau penjualnya (Sunyoto, 2014). Label merupakan sesuatu yang dilengketkan pada produk yang ditawarkan dan merupakan bagian dari kemasan. Di dalam label harus menjelaskan siapa yang membuat, di mana dibuat, kapan dibuat, cara menggunakannya waktu kadaluarsa, dan informasi lainnya (Sunyoto, 2014). Tipe-tipe label antara lain sebagai berikut:

a. Label merek (a brand label) adalah merek yang diletakkan pada produk atau kemasan atau semata-mata berfungsi sebagai merek.

b. Label tingkat kualitas (grade label), yaitu label yang mengidentifikasikan kualitas produk melalui huruf, angka atau abjad.

c. Label deskriptif (descriptive label), yaitu label yang memberikan informasi tentang penggunaan, pemeliharaan penampilan dan ciri lainnya.

Halal adalah boleh, pada kasus makanan kebanyakan makanantermasuk halal kecuali secara khusus disebutkan dalam Al Qur'an atau Hadis (Sunyoto, 2014). Jadi, labelisasi halal adalah proses pencantuman tulisan atau pernyataan halal pada kemasan produk untuk menunjukkan bahwa produk yang dimaksud berstatus sebagai produk halal.

Produk halal adalah produk pangan, obat, kosmetika dan produk lain yang tidak mengandung unsur atau barang haram dalam proses pembuatanya serta dilarang untuk dikonsumsi umat Islam baik yang menyangkut bahan baku, bahan tambahan, bahan pembantu 
lainya termasuk bahan produksi yang diolah melalui proses rekayasa genetika dan iradiasi yang pengolahanya dilakukan sesuai dengan syari'at Islam serta memberikan manfaat yang lebih daripada maḍarat (efek negatif) (Kementerian Agama, 2003).

a. Proses Pembuatan

Proses pembuatan atau proses produksi suatu perusahaan yang sudahmenggunakan label halal hendaknya harus tetap menjaga hal-hal sebagai berikut:

1) Binatang yang hendak dibersihkan, binatang yang sudah mati setelahdisembelih

2) Bahan campuran yang digunakan dalam proses produksi tidak terbuatdari barang-barang atau bahan yang haram dan turunanya.

3) Air yang digunakan untuk membersihkan bahan hendaklah air mutlakatau bersih dan mengalir.

4) Dalam proses produksi tidak tercampur atau berdekatan dengan barang atau bahan yang najis atau haram.

b. Bahan Baku Utama

Bahan baku produk adalah bahan utama yang digunakan dalam kegiatanproses produksi, baik berupa bahan baku, bahan setengah jadi maupun bahanjadi. Sedangkan bahan tambahan produk adalah bahan yang tidak digunakansebagai bahan utama yang ditambahkan dalam proses teknologi produksi (Sunyoto, 2014).

c. Bahan Pembantu

Bahan pembantu atau bahan penolong adalah bahan yang tidak termasukdalam kategori bahan baku ataupun bahan tambahan yang berfungsi untukmembantu mempercepat atau memperlambat proses produksi termasuk proses rekayasa (Sunyoto, 2014).

d. Efek

Makanan yang halal tidak boleh terlepas dari tujuan syari'at Islam, yaitu mengambil maslahah dan menolak madarat atau bahaya. Jika menurut kesehatan, suatu jenis makanan dapat membahayakan jiwa, maka makanan tersebut haram dikonsumsi. Allah berbelas-kasih kepada hambaNya, oleh karena itu dalam menentukan halal dan haram dengan alasan yang ma'qul (rasional) demi kemaslahatan manusia itu sendiri. Justru itu pula Allah tidak akan menghalalkan 
PENGARUH LABELISASI HALAL TERHADAP KEPUTUSAN PEMBELIAN PRODUK MI INSTAN

PADA MAHASISWA JURUSAN EKONOMI SYARIAH

INSTITUT AGAMA ISLAM NEGERI PADANGSIDIMPUAN

Darwis Harahap, Nando Farizal, Masbulan Nasution sesuatu kecuali yang baik, dan tidak akan mengharamkan sesuatu kecuali yang jelek (Qardhawi, 1993).

Label halal dapat dicantumkan ketika produsen memiliki sertifikasi halal atas produknya. Sertifikasi halal yang dikeluarkan LPPOMMUI menyatakan kehalalan suatu produk sesuai dengan syariat Islam, dan yang dimaksud dengan produk halal yang memenuhi syarat kehalalan sesuai syariat Islam yaitu (Sucipto, 2010);

1) Tidak mengandung babi atau produk-produk yang berasal dari babi serta tidak menggunakan alkohol sebagai ingredient yang sengaja ditambahkan.

2) Daging yang digunakan berasal dari hewan halal yang disembelih menurut tata cara syariat Islam.

3) Semua bentuk minuman yang tidak beralkohol.

4) Semua tempat penyimpanan, tempat penjualan, pengolahan, tempat pengolahan dan tempat transportasi tidak digunakan untuk babi atau barang tidak halal lainnya, tempat tersebut harus terlebih dahulu dibersihkan dengan tata cara yang diatur menurut syariat Islam.

Pemegang sertifikat halal dari LPPOM MUI bertanggungjawab memelihara kehalalan produk yang diproduksinya, dan sertifikat ini tidak dapat dipindahtangankan. Sertifikat Halal adalah fatwa tertulis yang dikeluarkan oleh MUIyang menyatakan kehalalan suatu produk yang merupakankeputusan sidang Komisi Fatwa MUI berdasarkan proses audityang dilakukan oleh LPPOM MUI (Hosen, 2008).

a. Proses Sertifikasi Halal

1) Setiap produsen yang mengajukan sertifikasi halal bagi produknya, pertamatama diharuskan mengisi formulir yang telah disediakan LPPOM MUI. Ada tiga macam formulir yang dapat digunakan dalam pengajuan ini, masing-masing untuk makanan dan minuman olahan, usaha restoran, dan hewan potong.

2) Surat pengajuan sertifikasi yang disampaikan ke LPPOM MUI harus dilampiri dengan sistem mutu, termasuk panduan mutu dan prosedur baku pelaksanaan yang telah disiapkan produsen sebelumnya.

3) Pada saat pengajuan sertifikat halal, produsen harus menandatangani pernyataan tentang kesediaannya untuk menerima tim pemeriksa (audit) dari LPPOM MUI dan memberikan contoh produk termasuk bahan baku, bahan penolong, dan bahan tambahan produk dapat diperiksa LPPOM MUI. 
4) Semua dokumen yang dapat dijadikan jaminan atas kehalalan produk yang diajukan sertifikasi halalnya harus diperlihatkan aslinya, sedangkan fotokopinya diserahkan kepada LPPOM MUI.

5) Surat pengajuan sertifikasi halal dan formulir yang sudah diisi dengan cermat beserta seluruh lampirannya dikembalikan kepada LPPOM MUI.

6) LPPOM MUI akan memeriksa semua dokumen yang dilampirkan bersama surat pengajuan sertifikasi halal. Jika tidak lengkap, LPPOM MUI akan mengembalikan seluruh berkas pengajuan untuk dapat dilengkapi oleh produsen pengusul.

7) Pemeriksaan audit ke lokasi produsen akan dilakukan oleh LPPOM MUI segera setelah surat pengajuan sertifikasi halal beserta lampiran-lampirannya dianggap sudah memenuhi syarat.

8) Setelah hasil pemeriksaan (audit) dievaluasi dan memenuhi syarat halal, maka produsen yang bersangkutan selanjutnya akan diproses sertifikasi halalnya.

9) Jika ada perubahan dalam bahan baku, bahan penolong, atau bahan tambahan dalam proses produksinya, produsen diwajibkan segera melapor ke LPPOM MUI untuk mendapatkan ketidakberatan menggunakannya (Sucipto, 2010).

b. Tata Cara Pemeriksaan (Audit) di Lokasi Produsen

1) Pada waktu yang sudah ditetapkan, tim LPPOM MUI yang dilengkapi dengan surat tugas dan identitas diri, akan mengadakan pemeriksaan (audit) ke perusahaan produsen yang mengajukan sertifikat halal.

2) Tim pemeriksa (auditor) akan mengambil contoh secara acak untuk kemudian diuji di laboratorium.

3) Jika diperlukan, pemeriksaan (audit) dapat dilakukan sewaktu-waktu secara tiba-tiba (Sucipto, 2010).

c. Pemberian Sertifikat Halal

1) Hasil pemeriksaan (audit) di lokasi produsen serta hasil analisis laboratorium diserahkan kepada MUI untuk dikeluarkan fatwa halalnya.

2) Setelah mendapatkan fatwa halal dari MUI, sertifikat halal dikeluarkan oleh LPPOM MUI.

3) Produsen yang medapatkan sertifikat halal dapat mengambil sertifikatnya di LPPOM MUI setelah membayar seluruh biaya sertifikasi yang telah dilakukan sebelumnya (Sucipto, 2010). 
PENGARUH LABELISASI HALAL TERHADAP KEPUTUSAN PEMBELIAN PRODUK MI INSTAN

PADA MAHASISWA JURUSAN EKONOMI SYARIAH

INSTITUT AGAMA ISLAM NEGERI PADANGSIDIMPUAN

d. Masa Berlakunya Sertifikasi Halal

Darwis Harahap, Nando Farizal, Masbulan Nasution

1) Sertifikat halal berlaku selama satu tahun, kecuali untuk daging impor sertifikasi halal hanya berlaku untuk setiap kali pengepakan.

2) Dua bulan sebelum berakhir masa berlakunya sertifikat, LPPOM MUI akan mengirim surat pemberitahuan kepada produsen yang bersangkutan.

3) Satu bulan sebelum berakhir masa berlakunya sertifikat, produsen harus mendaftarkan kembali untuk mendapatkan sertifikat tahun berikutnya.

4) Produsen yang tidak memperbaharui sertifikat halal, maka untuk tahun itu produsen tidak diizinkan lagi untuk menggunakan label halal berdasarkan sertifikat yang tidak berlaku dan akan diumumkan di berita berkala LPPOM MUI.

5) Pada saat berakhir masa berlakunya sertifikat, produsen harus segera mengembalikan sertifikat halal yang dipegangnya kepada LPPOM MUI (Sucipto, 2010).

\section{Produk Mi Instan}

Produk ialah penawaran yang memuaskan terhadap kebutuhan dari suatu organisasi. Siapapun konsumen, mereka membeli kepuasan dari produsen, bukan hanya produk. Sehingga jika berbicara tentang kepuasan, maka konsumen dapat puas dengan barang juga dengan pelayanan. Akibatnya, produk dapat dibagi kepada dua bagian, yaitu barang dan jasa (Ma'arif dan Tanjung, 2003).

Produk yang dibahas dalam penelitian ini adalah produk yang berupa barang, yaitu produk mi instan. Mi instan adalah sebuah produk yang dibuat dari tepung gandum ataupun tepung beras sebagai bahan utamanya dengan atau tanpa penambahan bahan lainnya. Mi instan memiliki keunikan pada gelombangnya. Gelombang yang ada pada produk mi instan memiliki fungsi untuk memaksimalkan proses pengukusan dan penggorengan. Proses penggorengan mi pada minyak yang panas akan membuat air dalam mi menguap sehingga menghasilkan struktur yang berlubang-lubang pada bagian dalam mi. tekstur ini yang membuat mi mudah mengalami proses hidrasi dan pemasakan (Ma'arif dan Tanjung, 2003).

Produk mi instan telah mendominasi pasar mi, hal ini terbukti banyaknya produk mi instan yang ada di pasaran baik yang ada di toko kelontong, minimarket, maupun supermarket. Tingginya permintaan konsumen terhadap mi merupakan peluang pasar yang potensial bagi pelaku usaha. Sehingga apabila mereka menginginkan untuk dapat memasuki pasar mi instan tersebut, maka perlu adanya informasi tentang karakteristik produk mi instan yang diinginkan 
konsumen. Secara umum karakteristik produk mi instan yang diinginkan konsumen dapat dilihat dari beberapa atribut yang menempel pada produk tersebut, seperti pada warna, ukuran, kemasan, label, rasa, dan lain sebagainya (Mulyadi dan Fauziah, 2014).

Beragam merek mi instan tersedia di pasaran dengan berbagai variasi rasa dan berbagai ukuran. Beberapa jenis mi instan yang beredar di pasar sudah bersertifikasi halal dan telah telah membuat label halal pada kemasannya, seperti merek Mie Sedap dengan variasi mie goreng, rasa kari ayam, rasa soto dan varian rasa lainnya. Merek lainnya yang sudah bersertifikasi halal adalah merek Indomie. Indomie yang dikenal akan variasi mie yang beragam mulai dari jenis mie goreng spesial, mie goreng cabe ijo, rendang, sate, kari ayam, rasa soto, juga ayam bawang sudah berlabel halal. Merek Supermi dengan varian rasa kari, soto, kaldu ayam, dan mie goreng juga sudah diakui kehalalannya oleh LPPOM-MUI.

\section{HASIL DAN PEMBAHASAN}

Pola konsumsi masyarakat muslim diatur oleh syariat Islam, Islam mendorong dan memberi kebebasan kepada individu agar membelanjakan hartanya untuk membeli barangbarang yang baik dan halal dalam memenuhi kebutuhan hidup. Kebebasan itu diberikan dengan ketentuan tidak melanggar batas-batas yang suci serta tidak mendatangkan bahaya terhadap keamanan dan kesejahteraan masyarakat dan Negara (Rozalinda, 2014).

Seorang Muslim tidak diperkenankan untuk mengonsumsi produk-produk yang tidak sesuai dengan syariat Islam. Dalam mengonsumsi produk, konsumen Muslim diatur dalam Alquran dan Al-hadist yang menjadi pedoman umat muslim. Dengan demikian, konsumen Muslim membutuhkan produk-produk pangan yang sudah terjamin kehalalannya yang akan membuat para konsumen Muslim merasa aman ketika mengonsumsinya.

Pencantuman label halal pada kemasan produk mi instan dilakukan untuk memberikan informasi dan perlindungan kepada konsumen muslim, dikarenakan adanya beberapa produsen yang menggunakan bahan-bahan produk pangan yang tidak halal namun tetap dipasarkan, yang dapat merugikan konsumen yang tidak mengetahuinya. Label halal dapat diperoleh oleh para produsen dari lembaga yang berwenang yaitu LPPOM-MUI dengan terlebih dahulu mengajukan sertifikasi halal terhadap produknya.

Dengan adanya label halal yang tercantum pada kemasan produk mi instan, maka secara langsung akan memberikan pengaruh bagi konsumen khususnya konsumenMuslim untuk menggunakan produk tersebut. Munculnya rasa aman dan nyaman dalam mengonsumsi produk tersebut akan meningkatkan kepercayaan serta minat konsumen. 


\section{KESIMPULAN}

Islam mendorong dan memberi kebebasan kepada individu agar membelanjakan hartanya untuk membeli barang-barang yang baik dan halal dalam memenuhi kebutuhan hidup. Kebebasan itu diberikan dengan ketentuan tidak melanggar batas-batas yang suci serta tidak mendatangkan bahaya terhadap keamanan dan kesejahteraan masyarakat dan negara. Dengan demikian, konsumen Muslim membutuhkan produk-produk pangan yang sudah terjamin kehalalannya yang akan membuat para konsumen Muslim merasa aman ketika mengkonsumsinya. Berdasarkan pada hasil analisis data dan pembahasan mengenai pengaruh labelisasi halal terhadap keputusan pembelian dengan metode analisis yang digunakan yaitu regresi sederhana, maka dapat ditarik beberapa kesimpulan bahwa ada pengaruh yang positif antara variabel labelisasi halal (X) terhadap keputusan pembelian (Y) yang terlihat dari persamaan regresi Keputusan Pembelian = 23,181 + 0,695 Labelisasi Halal + 0,115. Nilai koefisien regresi variabel labelisasi halal sebesar o,695 menunjukkan bahwa setiap kenaikan variabel labelisasi halal (X) sebesar 1 satuan akan meningkatkan keputusan pembelian (Y) menjadi sebesar 23,876 satuan dengan arah positif.Hal ini menunjukkan bahwa peningkatan labelisasi halal akan mempengaruhi peningkatan keputusan pembelian.

Nilai $R$ Square diperoleh sebesar o,291 menunjukkan bahwa variasi variabel keputusan pembelian produk mi instan pada Mahasiswa Jurusan Ekonomi Syariah Institut Agama Islam Negeri Padangsidimpuan dapat dijelaskan oleh variabel labelisasi halal sebesar 29,1\%, dimana sisanya 70,9\% dijelaskan oleh faktor-faktor lain di luar penelitian ini. Dari hasil uji t diperoleh $t_{\text {hitung }}>t_{\text {tabel }}(6,037>1,986)$ dan tingkat signifikansi yang diperoleh $0,000<\alpha(0,05)$ maka $\mathrm{H}_{\mathrm{o}}$ ditolak dan $\mathrm{H}_{\mathrm{a}}$ diterima. Jadi dapat disimpulkan bahwa dari hasil pengujian parsial koefisien labelisasi halal berpengaruh signifikan terhadap keputuan pembelian produk mi instan pada Mahasiswa Juruasan Ekonomi Syariah IAIN Padangsidimpuan.

\section{DAFTAR PUSTAKA}

Agus Sucipto, Studi Kelayakan Bisnis, Malang: UIN-MALIKI PRESS (Aggota IKAPI), 2010.

Bagian Proyek Sarana Dan Prasarana Produk Halal Direktorat Jenderal Bimbingan Masyarakat Islam Dan Penyelenggaraan Haji, Petunjuk Teknis Pedoman System Produksi Halal, Jakarta: Departemen Agama RI, 2003.

Basu Swastha Dharmmesta dan Hani Handoko, Manajemen Pemasaran: Analisis Perilaku Konsumen, edisi pertama, Yogyakarta: BPFE-Yogyakarta (Anggota IKAPI), 2016.

Buku Profil Fakultas Ekonomi dan Bisnis Islam IAIN Padangsidimpuan 2016. 
Danang Sunyoto, Dasar-dasar Manajemen Pemasaran: Konsep, Strategi, dan Kasus, Yogyakarta: CAPS (Center of Academic Publishing Service), 2014.

Departemen Agama RI, Al Quran dan Terjemahannya, Bandung: Penerbit Diponegoro, 2006.

Husein Umar, Metode Penelitian Untuk Skripsi dan Tesis, Edisi Kedua, Jakarta: Rajawali Pers, 2013 .

Ilfi Nur Diana, Hadis-hadis Ekonomi, Malang: UIN Maliki Press (Anggota IKAPI). 2012.

Juliansyah Noor, Metodologi Penelitian: Skripsi, Tesis, Disertasi, dan Karya Ilmiyah, Jakarta: Kencana Prenada Media Group. 2013.

Kasmir dan Jakfar, Studi Kelayakan Bisnis, edisi kedua, cetakan ketujuh (Jakarta: Kencana. 2010.

Leon G. Schiffman dan Leslie Lazar Kanuk, Prilaku Konsumen, edisi ketujuh, Jakarta: Indeks, 2004 .

M. Syamsul Ma'arif dan Hendri Tanjung, Manajemen Operasi, Jakarta: PT. Grasindo. 2003.

Mohamad Nadratuzzaman Hosen, Panduan Umum Sistem Jaminan Halal LPPOM-MUI, Lembaga Pengkajian Pangan Obat-obatan dan Kosmetika Majelis Ulama Indonesia, 2008.

Morissan, Periklanan: Komunikasi Pemasaran Terpadu, Jakarta: Kencana, 2010.

Mudjarad Kuncoro, Metode Riset Untuk Bisnis Dan Ekonomi, Jakarta: Erlangga, 2009.

Nugroho J. Setiadi, Perilaku Konsumen: Perspektif Kontemporer pada Motif, Tujuan, dan Keinginan Konsumen, edisi revisi, Jakarta: Kencana, 2010.

Philip Kotler dan Kevin Lane Keller, Manajemen Pemasaran, edisi kedua belas, Jakarta: Indeks, 2007.

Rozalinda, Ekonomi Islam: Teori dan Aplikasinya pada Aktivitas Ekonomi, Jakarta: Rajawali Pers, 2014.

Sambas Ali Muhidin dan Maman Abdurrahman, Analisis Korelasi, Regresi, dan Jalur dalam Penelitian (Dilengkapi Aplikasi Program SPSS), Bandung: Pustaka Setia, 2009.

Soegyarto, Statistik Lanjutan, Jakarta: PT. Rineka Cipta, 2004.

Sugiyono, Metode Penelitian Bisnis, Bandung: Alfabeta, 2012. ,Metode Penelitian Manajemen, Bandung: Alfabeta, 2016.

Suharsimi Arikunto, Manajemen Penelitian, Jakarta: Rineka Cipta. 2013.

Tarigan, Azhari Akmal, dkk., Dasar-dasar Ekonomi Islam (Bandung: Citapustaka Media, 2006.

Ujang Sumarwan, dkk., Riset Pemasaran dan Konsumen, Bogor: PT. Penerbit IPB Press, 2013. 
PENGARUH LABELISASI HALAL TERHADAP KEPUTUSAN PEMBELIAN PRODUK MI INSTAN

PADA MAHASISWA JURUSAN EKONOMI SYARIAH

INSTITUT AGAMA ISLAM NEGERI PADANGSIDIMPUAN

Darwis Harahap, Nando Farizal, Masbulan Nasution

Ujang Sumarwan, Perilaku Konsumen: Teori dan Penerapannya dalam pemasaran, edisi kedua, Bogor: Ghalia Indonesia, 2015.

Yazid Abu Fida', Ensiklopedi Halal Haram Makanan, Solo: Pustaka Arafah, 2014.

Yusuf Qardhawi, Halal dan Haram dalam Islam, Alih bahasa: Mu'ammal Hamidy, Jakarta: PT. Bina Ilmu, 1993.

Sumber Lain:

Andri Mulyadi dan Elys Fauziyah, "Preferensi Konsumen dalam Pembelian Mi Instan di Kabupaten Bangkalan” Jurnal Sosial Ekonomi dan kebijakan Pertanian, vol 3 no. 1, 2014, (journal.trunojoyo.ac.id), diakses 29 Desember 2016 pukul 15.06.

Asthami, dkk., "Mie Instan Belalang Kayu (Melanoplus cinereus): Kajian Pustaka” Jurnal Pangan dan Agroindustri, vol. 4 no.1, 2016, (jpa.ub.ac.id), diakeses 29 Desember 2016 pukul 14.49.

LPPOM MUI. http://lppommui.org/journal/Sertifikasi_dan_Labelisasi_Halal, diakses 20 Desember 2016 pukul 13:54.

Profil Jurusan Ekonomi Syariah Fakultas Ekonomi dan Bisnis Islam IAIN Padangsidimpuan (http://ekonomi-islam.iain-padangsidimpuan.ac.id), diakses tanggal 16 Februari 3017.

Wawancara dengan Siti Fatimah, Mahasiswa Jurusan Ekonomi Syariah Institut Agama Islam Negeri Padangsidimpuan, tanggal 17 Januari 2017, pukul 11:15.

Wawancara dengan Sri Devi, Mahasiswa Jurusan Ekonomi Syariah Institut Agama Islam Negeri Padangsidimpuan, tanggal 17 Januari 2017, pukul 10:30.

AHLUL BAIT INDONESIA. www.ahlulbaitindonesia.or.id, diakses 20 Desember 2018.

HALAL MUI. www.halalmui.org, diakses 21 Desember 2018. 